\title{
Afterword: Rethinking Western Printing With Chinese Comparisons
}

\section{Citation}

Blair, Ann. 2011. "Afterword: Rethinking Western printing with Chinese comparisons." In Knowledge and Text Production in an Age of Print: China, 900-1400, edited by Lucille Chia and Hilde de Weerd. 349-360. Leiden, the Netherlands: Brill.

\section{Published Version}

doi:10.1163/ej.9789004192287.i-430.78

\section{Permanent link}

http://nrs.harvard.edu/urn-3:HUL.InstRepos:29674923

\section{Terms of Use}

This article was downloaded from Harvard University's DASH repository, and is made available under the terms and conditions applicable to Other Posted Material, as set forth at http:// nrs.harvard.edu/urn-3:HUL.InstRepos:dash.current.terms-of-use\#LAA

\section{Share Your Story}

The Harvard community has made this article openly available.

Please share how this access benefits you. Submit a story.

Accessibility 
Ann Blair, Dept of History, Harvard University

published in Knowledge and Text Production in an Age of Print - China, Tenth$\underline{\text { Fourteenth Centuries, }}$ ed. Lucille Chia and Hilde de Weerdt, Sinica Leidensia 100 (Leiden: Brill, 2011), pp. 349-60.

\section{Afterword: Rethinking Western Printing with Chinese Comparisons}

Historians of the book of all specialisms, but especially those pondering the impact of printing in Europe or elsewhere, stand much to gain from a volume like this one which tackles a big question --the impact of printing in China between $10^{\text {th }}$ and $14^{\text {th }}$ centuries-- by focusing in careful detail on specific causal factors, genres of writing and cultural milieux. To focus on broad generalizations about the impact of printing, in China or in Europe, let alone across the two, is to risk ignoring the multiple and sometimes contradictory trends that printing fostered. In both Europe and China printing increased the speed with which multiple copies of a text, map or image could be produced, though the technology and economics involved in the use of woodblock versus movable metal type were different in important ways. Despite those and many contextual differences, there are also similarities between many of the themes presented in this volume and in the recent historiography on early modern European printing-- from the enthusiasm for printing as a response to loss and a means of education to the fears of subversion or loss of textual quality that printing also prompted.

\section{Ecology of media}

The articles in this volume do a splendid job of emphasizing that printing emerged within an existing ecology of media, including (as in Europe) oral 
communication and the circulation of manuscripts, but also other media such as stone inscriptions and stelae. In the Chinese as in the European case printed texts have become privileged sources for historians because in the long run the multiplicity of copies favored textual survival better than manuscripts of the highest quality or inscription on the hardest surfaces--in other words, the single priceless manuscript or massive stone inscription was more likely to be destroyed than all the copies of a much printed text. But at the time of production the printed text was only one of many means by which those publishing (whether on a government or an individual initiative) could diffuse their material. In many genres, from local gazetteers to scholarly commentaries, manuscript continued to play an important role in the circulation of information to smaller, selected sets of readers (as discussed by McDermott, Chia, Hinrichs, De Weerdt and Dennis in this volume) and in some areas stone inscriptions also continued to diffuse information in a more circumscribed geographical area.

Similarly, recent work on early modern Europe and the American colonies has emphasized the persistent role of manuscript in various genres where small circulation was the goal: including chamber music parts, poetry and satire designed to circulate narrowly among family and friends, and political newsletters or texts which would be considered politically or religiously subversive if printed. ${ }^{1}$ Oral diffusion is also beginning to feature more prominently in the studies of early modern media, notably the

\footnotetext{
${ }^{1}$ Harold Love, Scribal Publication in Seventeenth-Century England (Oxford: Oxford University Press, 1993) and, more generally, "Early modern print culture: assessing the models," Parergon. Journal of the Australian and New Zealand Association for Medieval and Early Modern Studies 20 (2003): 45-64; Peter Beal, In Praise of Scribes: manuscripts and their makers in seventeenth-century England (Oxford: Clarendon Press, 1998); David D. Hall, Ways of Writing: the practice and politics of text-making in seventeenth-century New England (Philadelphia: University of Pennsylvania Press, 2008).
} 
role of sermons that were such a regular fixture of life for Catholics and Protestants alike but the significance of which is less well understood in Chinese contexts. Theater was another oral form that reached wide audiences. ${ }^{2}$ More comparable across European and Chinese cultures were the personal and epistolary interactions among scholars which form the broader context in which they engaged with one another and a broader audience in print. In Europe the periodical emerged as a new genre for that purpose starting in the late $17^{\text {th }}$ century. ${ }^{3}$

The process of printing

As others have pointed out, printing in China, primarily by woodblock, presented different "affordances" from metal movable type used for printing text in Europe. ${ }^{4}$ Carving a woodblock from a manuscript required cheap materials (wood and some tools) and minimal skill, not even literacy, and once made a woodblock could be reused until it

\footnotetext{
${ }^{2}$ On sermons see Beverly Kienzle, ed., The Sermon, Typologie des sources du moyen âge occidental (Turnhout: Brepols, 2000); Bruce R. Smith, The Acoustic World of Early Modern England: Attending to the O-Factor (Chicago: University of Chicago Press, 1999); Larissa Taylor, ed., Preachers and People in the Reformation and Early Modern Period (Leiden: Brill, 2001). On the theater see Julie Stone Peters, Theatre of the Book: print, text and performance in Europe (Oxford: Oxford University Press, 2003) and Bryan Crockett, The Play of Paradox: Stage and Sermon in Renaissance England (Philadelphia: University of Pennsylvania Press, 1995).

${ }^{3}$ On the Republic of Letters see Anne Goldgar, Impolite Learning: conduct and community in the Republic of Letters 1680-1750 (New Haven: Yale University Press, 1995); Hans Bots and Françoise Waquet, La république des lettres (Paris: Belin, 1997). Correspondence networks warrant more study; see for example Candice de Lisle, "Establishing the Facts: Conrad Gessner's Epistolae medicinales between the particular and the general," Ph.D. dissertation University College London, 2009. Thomas Broman, "Periodical Literature," in Maria Frasca-Spada and Nick Jardine, eds., Books and the Sciences in History (Cambridge: Cambridge University Press, 2000), 225-38.

${ }^{4}$ I have borrowed the term from Abigail J. Sellen and Richard H. R. Harper, The Myth of the Paperless Office (Cambridge, Mass: MIT Press, 2002), 17-18 to designate the features which are facilitated and made more difficult by the physical properties of an object or process.
} 
was worn out (which estimates place at about 15,000 copies). With low initial outlay required, works could be printed in small quantities at first, to be complemented by later printings over a long period, as Joseph Dennis describes was expected of gazetteers. By contrast in Europe, by the mid- $16^{\text {th }}$ century, a smoothly operating handpress typically employed three people (a compositor, an inker and a pressman) to produce 1000-1250 copies of one side of one sheet of paper per day; the next day those sheets would be printed on the other side, producing that many copies of one quire--a quire comprised eight double-sided leaves (sixteen pages) of an octavo format book, or four leaves (eight pages) of a quarto format. ${ }^{5}$ Setting the type for one sheet required a full day's work on the part of a skilled compositor using costly metal type that had to be available in sufficient quantities.

Once the type was set it was imperative to print as many copies as might possibly be hoped to sell, since after the run was complete, the type would be redistributed into the cases where it was stored until used to set another sheet. To reprint anything required the same investment of time and resources as the initial printing (save for planning the layout of the page). Thus Gutenberg's printing process required a high initial investment in

\footnotetext{
${ }^{5}$ For a primary account see Johan Gerritsen, "Printing at Froben's: an eye-witness account (c. 1534)," Studies in Bibliography (Virginia) 44 (1991), 144-63. On material bibliography (quires etc) see Philip Gaskell, A New Introduction to Bibliography (Winchester: St Paul's Bibliographies and New Castle, Delaware: Oak Knoll Press, 1995). On early printing in general see Lucien Febvre and Henri-Jean Martin, The Coming of the Book: the impact of printing 1450-1800, tr. David Gerard, ed. Geoffrey Nowell-Smith and David Wootton (London: N.L.B., 1976); Rudolf Hirsch, Printing, Selling and Reading 1450-1550 (Wiesbaden: Harrassowitz, 1974); and David McKitterick, Print, Manuscript, and the Search for Order, 1450-1830 (Cambridge: Cambridge University Press, 2003).
} 
metal type and skilled labor, which could be recovered only if enough copies were sold. Early modern printers were regularly bankrupted by the risky economics of a speculative business which tied up capital with no guarantee of sufficient returns. Many, perhaps most, of the great humanist printers died leaving deep debts. Some were bankrupted by their production of large scholarly works that sold poorly, like Henri Estienne's Thesaurus Linguae Latinae, which is still valued today for its high level of scholarship and accuracy. ${ }^{6}$

For the historian each system brings it own caveats. In China it is impossible to estimate from one surviving copy of a book how many other copies were printed, when and with what level of similarity (since woodblocks could be modified along the way), but one can presume that most copies found users, since there was limited incentive to overproduce. In Europe we can conclude from one surviving copy that (depending on the context) at least 300 or 500 or 1000 other copies were printed at the same time, with the potential for usually small variations in the form of stop-press corrections and cancels. But we must also remember that speculative overproduction was the only strategy by which a profit could be made. Thus one historian of the book has wisely concluded that in the European system "most printed books have never been read."

\footnotetext{
${ }^{6}$ On the financial difficulties of the great Basel printer Johannes Oporinus, see Martin Steinmann, "Aus dem Briefwechsel des Basler Druckers Johannes Oporinus," Basler Zeitschrift für Geschichte und Altertumsgeschichte 69 (1969):103-203, e.g.189-90. On Henri Estienne: John Considine, Dictionaries in Early Modern Europe: Lexicography and the Making of Heritage (Cambridge: Cambridge University Press, 2008), ch. 2, 93. ${ }^{7}$ Hugh Amory, "The Trout and the Milk: An Ethnobibliographical Talk," Harvard Library Bulletin 7 (1996): 50-65, 51.
} 
Initially, the dominant reaction to printing was one of great admiration for it as a "divine invention." ${ }^{8}$ Contemporaries were impressed with the labor that printing saved, although quantitative estimates of the savings varied and are probably more rhetorical than reliable: one contemporary marveled that "as much can be printed by one man in a day as could be written in a whole year by many scribes." With more realistic attention to the infrastructure involved in a print shop (where more than one person was generally employed), an Englishman in 1630 estimated that four men could print in a day what it used to take ten men a whole year to write by quill. ${ }^{9}$ Contemporaries also noted a great drop in book prices due to printing. Printing made books affordable to greater numbers than before, as various humanist observers noted, whether they felt this was for the better (Andrea de Bussi, Ludovico Carbone) or for the worse (e.g., Hieronymo Squarcifico). ${ }^{10}$

At first printed books closely mimicked manuscripts: they used the same scripts, had no foliation or title page, and left blank spaces for initials to be filled in with rubrication by hand. By 1530 the features we associate with the modern printed book had become

\footnotetext{
${ }^{8}$ See Elizabeth Eisenstein, Printing as Divine Art: Celebrating Western Technology in the Age of the Handpress (Oberlin: Oberlin College, 1996) and Divine Art / Infernal Machine: The Reception of Printing in the West (forthcoming University of Pennsylvania Press).

${ }^{9}$ For this and other examples, see McKitterick, Print, Manuscript and the Search for Order, 100-101, 49. Comment of 1630 by Henricus Salmuth (b. 1592) in Guido Pancirolli, Rerum memorabilium sive deperditarum pars prior commentariis (Frankfurt: Tampachius, 1629-31), 252.

${ }^{10}$ In 1468 Cardinal Bussi reported that a text that would have cost 100 guilders could be had for 20 when printed, as quoted in Hirsch, Printing, Selling and Reading, 1, 69. These and other examples from Jean-François Gilmont Le Livre et ses secrets_(Geneva: Droz, 2003), 49-50, and Brian Richardson, "The Debates on Printing in Italy," La Bibliofilia 100 (1998), 135-55, 139-41. On Squarcifico's complaint, see Martin Lowry, The World of Aldus Manutius (Ithaca: Cornell University Press, 1979), 15. See also the complaints of Trithemius about the poor durability and quality of printed books and the paper they were printed on: Johannes Trithemius, In Praise of Scribes: De laude scriptorum, ed. Klaus Arnold, tr. Roland Behrendt (Lawrence, KS: Coronado Press, 1974), 34-35, 64-65.
} 
standard: a title-page, crucial for tempting buyers, foliation at first (numbering only the verso of each page) then pagination which were the normal form of reference used in indexes, tables of contents and errata lists; and the use of blank space and typographical symbols (dingbats) or variations in font size and type to mark divisions in the text rather than the manual application of color. ${ }^{11}$

Motivations for printing

In both Europe and China printing was the initiative of someone other than the end-user. The government played a uniquely powerful role in China, notably in launching in the late $10^{\text {th }}$ century the large scale collection and printing of the classics, but also throughout the period medical texts, gazetteers and histories, among other genres. In Europe printing was predominantly commercial from the beginning, although not exclusively. Among the earliest imprints were large quantities of indulgences, commissioned by the Church for sale to the faithful who would buy them in penance for their sins. Perhaps as many as one million of these single-sided imprints were sold, to be filled in with the buyer's name in manuscript, though only a few hundred are still extant;

\footnotetext{
${ }^{11}$ On the development of the "modern book," see Febvre and Martin, ch. 3, and HenriJean Martin, La naissance du livre moderne: mise en page et mise en texte du livre français XIVe-XVIe siècles (Paris: Editions du Cercle de la Librairie, 2000), esp. 31 on the blackening of the page. On forms of reference see Paul Saenger, "The Impact of the Early Printed Page on the History of Reading," Bulletin du bibliophile (1996), 237-301; on the title page, Jean -François Gilmont and Alexandre Vanautgaerden, eds., La page de titre à la Renaissance (Turnhout: Brepols, 2008) and Margaret M. Smith, The Title-Page. Its Early Development, 1460-1510 (London: British Library and Newcastle, DE: Oak Knoll Press, 2000).
} 
since they were typically kept as loose paper they were especially vulnerable to destruction and re-use. ${ }^{12}$

Though the publishing contexts were different, some of the motivations behind the rise of printing in early Song China and Renaissance Europe were similar. The desire to recover from great losses of books motivated the Song emperors to launch large scale collecting and printing of the classics to replenish the court library as well as local government and private libraries. In Europe humanists of the late $14^{\text {th }}$ and $15^{\text {th }}$ centuries were keenly aware of the loss of ancient literature during a period that Petrarch first called the "dark" or "middle ages." Operating on their own or on behalf of wealthy patrons, Italian humanists started seeking out long-forgotten manuscripts in European and Byzantine libraries well before Gutenberg's invention ca 1453. But when printing became available humanists hailed the technology as the means to prevent future losses of the painstakingly recovered texts. Editiones principes or first editions of ancient texts, with facing Latin translations for those texts in Greek, comprised a significant proportion of incunabula (books printed before 1500). In the sixteenth century some commented that if the ancients had had printing, their works would not have been lost. ${ }^{13}$ In 1545 Conrad Gessner compiled a massive bibliography of all known works in Latin, Greek and Hebrew totaling some 10,000 texts by 3,000 authors. Many of them had been recently printed, but some were still available only in manuscript while others were known only

\footnotetext{
${ }^{12}$ For example, of the two hundred thousand indulgences printed between 1498 and 1500 at the behest of the Benedictines of Montserrat in Catalonia, only six survive; see Paul Needham, The Printer and the Pardoner: An Unrecorded Indulgence Printed by William Caxton (Washington, DC: Library of Congress, 1986), 31. See also Falk Eisermann, "The Indulgence as a Media Event: Developments in Communication through Broadside in the Fifteenth Century," in Promissory Notes on the Treasury of Merits: Indulgences in Late Medieval Europe, ed. R. N. Swanson (Leiden: Brill, 2006), 309-30.

${ }^{13}$ Richardson, "The Debates on Printing," 141.
} 
through citations in other works and Gessner eagerly hoped that calling attention to them in his bibliography would facilitate their recovery.

Those who witnessed the rise of printing in China and Europe were conscious of the boon to survival that reproduction in multiple copies represented. Conversely, texts omitted from large printing projects in China could be knowingly consigned to oblivion and loss. And despite the best efforts of humanists and of the classical scholars who carried on their work into the modern period, at most $20 \%$ of ancient literature is extant today. ${ }^{14}$ In China too the losses which printing was meant to palliate cover vast numbers of texts, although quantifying these losses an unresolved question.

At the same time as printing was praised for its power of preserving texts by multiplying them faster and in greater quantities, printing had consequences that contemporaries found distressing. In both China and Europe scholars complained about the risks of low quality imprints. Indeed the first calls for censorship in Europe were made by humanists hoping to regulate the quality of manuscripts used in making printed editions of classical texts; Italians especially complained of the German printers working in Italy that they were bent on making profits without heed to scholarly quality. These calls for the regulation of scholarly works in classical languages went unheeded by Church and state authorities, but all these agencies instituted censorship once the success of the Protestant movement had demonstrated the power of printed texts, especially vernacular pamphlets calling for religious rebellion not only against Catholic institutions,

\footnotetext{
${ }^{14}$ Bardon estimates that writings survive for only 20 percent of the Latin authors we know existed, but those authors wrote other works now lost and there were of course authors of whose existence we have no trace; Henry Bardon, La Littérature latine inconnue (Paris: Klincksieck, 1952), 13.
} 
but also, soon thereafter, against the wishes of the Refomers themselves. ${ }^{15}$ By midsixteenth century Protestant and Catholic churches and governments had set up mechanisms for regulating printed books, by requiring approval prior to printing (prepublication censorhip) and by attempting to block the circulation of books they considered bad once they had been published (often elsewhere).

In China as in Europe attempts at prohibiting undesirable imprints were not very effective, despite regulations in place to punish anyone associated with a forbidden book, whether as author, printer, seller, or owner. In China where the distances were vast and where printing required little set-up and could be performed on the fly, censorship was particularly difficult. In Europe printers were generally immobilized by their investment and the heavy equipment they required in highly visible urban centers, but the books themselves could be smuggled across the many religious and political borders that fragmented early modern Europe. If control of printing was effective in some times and places (late $16^{\text {th }}$-century Spain, or Calvin's Geneva) through pre-publication censorship, control of the circulation of books once they were printed was much more difficult to enforce. The Catholic Church went to the greatest lengths to ban and expurgate books once printed (notably in Protestant areas): the Index of Forbidden Books was printed regularly with lists of banned books and instructions to owners for the removal of offending passages from books which were considered salvageable. Surviving copies attest to the wide range of practices of post-publication censorship: in some cases pages

\footnotetext{
${ }^{15}$ John Monfasani, "The First Call for Press Censorship," Renaissance Quarterly 41 (1998), 1-31; John Davies, "Making Sense of Pliny in the Quattrocento" Renaissance Studies 9 (1995), 240-57; and Rudolf Hirsch, "Pre-Reformation Censorship of Printed Books," in The Printed Word: Its Impact and Diffusion (London: Variorum Reprints, 1978).
} 
were torn out or words blackened beyond reading, according to instructions, but many censored books were annotated with striking-out and marginal notes signaling the passages to be deleted which nonetheless remained fully legible. ${ }^{16}$

\section{Cultural attitudes}

The articles in this volume have also tried to gauge the impact of printing on cultural attitudes toward books, from collecting them to reading and responding to them. These are difficult assessments because it is hard to dissociate the impact of printing from other cultural phenomena which may be independent of it; in Europe in particular humanism and movements of church reform were underway before printing, though printing clearly shaped the forms and outcomes of these movements. Secondly, individual attitudes often varied and the historian is hard pressed to determine which reaction is idiosyncratic and which more representative in a particular context.

Certainly one impact well documented in this volume as well as in early modern Europe is the rise in the size and number of private libraries. Authors in this volume document an increase in the size and number of private libraries (though a region rich in libraries in one period might decline in a later one) and more diverse holdings as the kinds of texts being printed diversified beyond the authors canonized as of the first rank (McDermott). In Europe the growing size of libraries can be documented from inventories after death as well as owners who cataloged their own books. To choose just a few results

\footnotetext{
${ }^{16}$ On Catholic censorship see Gigliola Fragnito, ed., Church, Censorship, and Culture in Early Modern Italy, tr. Adrian Belton (Cambridge: Cambridge University Press, 2001); Jesus Martinez de Bujanda, ed., Index des livres interdits, 8 vols. (Sherbrooke, Canada: Université de Sherbrooke, and Geneva: Droz, 1984-2002). Protestant censorship existed too, but did not often leave records in print; it remains to be studied from local archives.
} 
from among the growing numbers of studies of book ownership, a typical French royal magistrate in the late 15 th century might have owned 60 books; one hundred years later Montaigne remarked that he owned about 1000 books, in what would have been a large private library for the time; in the early eighteenth century another famous French provincial magistrate, Montesquieu, owned over 3000 books. ${ }^{17}$ Starting in the $17^{\text {th }}$ century a new genre offered advice on "erecting a library," which explained which books to choose, how to arrange them and the furniture useful to shelve them. Another new genre listed famous libraries of the time, providing models for admiration and imitation. ${ }^{18}$

But even in the face of an increasing range of books available through printing, early modern European scholars differed in their attitudes toward those books. Some recommended owning and reading few books, but the best ones, invoking religious reasons (like the Jesuit Antonio Possevino) or pedagogical ones (like the Jesuit Francesco Sacchini).

17 Estimates for book ownership among the Parisian magistrates of the late middle ages are from Geneviève Hasenohr, "L'essor des bibliothèques privées aux XIVe et XVe siècles," in Histoire des Bibliothèques Françaises, I: Les Bibliothèques médiévales, du VIe siècle à 1530, ed. André Vernet (Paris: Promodis, 1988), 215-63, 239. I owe the comparison of Montaigne and Montesquieu to Peter Burke, A Social History of Knowledge 1500-1800. From Gutenberg to Diderot (Cambridge, U.K.: Polity Press, 2000), 191-92. On Montesquieu's library, see Louis Desgraves and Catherine Volpilhac-Auger, Catalogue de la Bibliothèque de Montesquieu à La Brède (Naples: Liguori, 1999). The case of Montaigne's library is more complicated: Pierre Villey, Les sources et l'évolution des Essais de Montaigne, 2 vols. (Paris: Hachette, 1908), I, 244-70, bases his list of 271 titles primarily on Montaigne's borrowings in the Essais; Montaigne refers to his one thousand volumes in Essais, III, 12, ed. Pierre Villey (Paris: Presses Universitaires de France, 1988), 1056b. For the most recent discussion, see Gilbert de Botton and Francis Pottiée-Sperry, "A la recherche de la 'librairie' de Montaigne," Bulletin du bibliophile 2 (1997), 254-80. I am grateful on this point to the expertise of George Hoffmann.

${ }^{18}$ The most famous advice manual is Gabriel Naudé, Advis pour dresser une bibliothèque (1627); an English translation of 1661, is available in fascimile as Instructions Concerning Erecting of a Library (Cambridge: Houghton Mifflin, 1903). For a guide to the best libraries of Europe, see Louis Jacob de Saint-Charles, Traité des plus belles bibliothèques publiques et particulières (Paris: Rolet le Duc, 1644); he named as an antedecent Claude Clément, Musei sive bibliothecae tam privatae quam publicae extructio, instructio, cura, usus (Lyon: Jacob Prost, 1635) for its description of the Escorial library. 
Others, on the contrary, exulted in abundance and recommended owning as many books as possible, containing many different opinions. Thus Gabriel Naudé (also a Catholic) included the works of heretics among the books one have in one's library, and the Jesuit Jeremias Drexel explained how to take notes on large numbers of books (he mentioned "reading" as many as 600 in one day!) in order to have material ready for composing or speaking on any topic in any context. ${ }^{19}$ This range of positions among Catholics and even within the Jesuit order, which was mirrored by a similar range among Lutherans and Calvinists, cannot be explained by a particular element of context. Humanists could justify both the preference for a narrow canon and the broad eclectic approach to the increased availability of books by turning to equally respected ancient authorities. On the one hand the Roman moralist Seneca warned against the distraction posed by too many books and advocated reading carefully just three or four books, but well-chosen ones ("destringit multitudo librorum"). On the other hand the Roman encyclopedist Pliny the Elder, author of a Natural History in 38 books, was quoted in the letters of his nephew as quipping that "there is no book so bad that some good cannot be gotten of it." This tag was repeated by those who exulted in abundance, from Gessner to Naudé and Drexel, while Seneca was favored by those who felt instead that "less is more. ${ }^{20}$ Nonetheless, even for those who resented the fact, printing certainly fostered an awareness of more different genres and opinions, in Europe as in China.

\footnotetext{
${ }^{19}$ Jeremias Drexel, Aurifodina artium et scientiarum omnium (Antwerp: vidua Ioannis Cnobbari, 1638), 87.

${ }^{20}$ Seneca, Ad Lucilium epistulae morales, II, 3, in tr. Richard Gunmere (Cambridge, Mass.: Harvard University Press, 1917), I, 6-9; Pliny the Younger, Letters, III, v (to Baebius Macer) in Letters and Panegyricus, tr. Betty Radice (Cambridge, Mass.: Harvard University Press,1969), I, 176-77; see Conrad Gesner, Bibliotheca universalis (Zurich: Froschauer, 1545), sig *3v; Naudé, Instructions Concerning Erecting of a Library, 33.
} 
Even more elusive, as authors in this volume point out, is the claim that critical thinking developed as a result of the increased availability of printed books. Italian humanists deployed critical reasoning in their analysis of texts well before the advent of printing. A classic example is Lorenzo Valla's debunking of the Donation of Constantine based on philological arguments among others; composed in 1440, it was printed only in 1518. The same critical skills used to ferret out forgeries were also deployed by humanists to make new and better forgeries that suited the points they hoped to make about the antiquity of a certain text or the origins of a certain people. ${ }^{21}$ For example some humanists supported claims that their nation (English or German or French) had descended from escapees from Troy, to match the origin story of the Romans descended from Aeneas as told by Vergil. Just as Sima Guang in the $11^{\text {th }}$ century applied critical skills selectively to suit his other commitments, as Egan describes in this volume, so too European humanists studied history principally in order to support current positions and projects. In short, critical thinking can be found before printing and "credulousness" well after printing, so that the abundance of books does not readily appear to be a cause of the more systematic application of new modes of reasoning.

One consequence of printing in Europe which is both hard to quantify precisely and yet hard to question is the rise of literacy. Measuring literacy is fraught with factors favoring both overestimates (signing one's name might be learned separately from reading) and underestimates (we typically measure writing, but writing was taught after reading, so more people could read than could write). Local studies have shown that literacy varied widely by

${ }^{21}$ Anthony Grafton, Forgers and Critics: creativity and duplicity in Western scholarship (Princeton : Princeton University Press, 1990) and What Was History? The art of history in early modern Europe (Cambridge: Cambridge University Press, 2007). 
context. Throughout Europe men and urban populations acquired literacy in greater numbers than women and rural populations, but within those broad parameters there were great variations and multiple trends, including stagnation or even decreases in literacy in certain times and places. A highly literate environment like Renaissance Venice had some 33\% male literacy and $13 \%$ female literacy in 1480, while the European average was much lower then. Literacy rates increased more or less rapidly during the $16^{\text {th }}-18^{\text {th }}$ centuries. By the 1740s French reached on average $60 \%$ male literacy in cities, whereas due to an active educational policy Sweden reached rates of $90 \%$ literacy by $1700 .{ }^{22}$ The lowered cost and increased availability of books favored the acquisition of literacy, not only by children but by adults who could teach one another or themselves to read from cheap print. The study of Chinese literacy rates no doubt poses unique challenges, but it would be interesting to investigate the extent to which increases in the production of printed books correlated with changes in literacy rates.

Historical assessments of the impact of printing are best carried out with attention to specific cultural contexts, to the range of contemporary disagreements, and of historical arguments and counterarguments. For Europeanists, learning about the impact of printing in China offers a valuable counterpoint to the tendency to universalize the European experience. What we call "printing" was not a single technology-- $19^{\text {th }}$ century linotype and stereotype offer many of the advantages of xylography but in an industrial rather than a premodern context. Nor did it have the same effects everywhere. In Europe printing was principally commercial in nature and spread rapidly, across some 50 cities in the first 50

${ }^{22}$ Venice figures from Brian Richardson, Printing, Writers and Readers in Renaissance Italy (Cambridge: Cambridge University Press, 1999), 110. Other figures from R. A. Houston, Literacy in Early Modern Europe: culture and education 1500-1800 (London: Longman, 1988), 150, 167 and 166-71 for more examples. 
years, producing an estimated 27,000 incunabula, each in at least hundreds of copies. ${ }^{23} \mathrm{In}$ China printing facilitated the circulation and accumulation of books, but only once initiatives by the imperial government, then by scholars and printers broadened the range of print beyond the beyond the narrower repertoire of religious texts or calendars to which it was limited for the first centuries after its invention. In Europe printing was invented at a time when significant new cultural movements were more or less far underway including voyages of discovery, Renaissance humanism, and religious reform, so that it is especially hard to weigh the impact of printing independently of these major developments, each of which emerged from a complex causal nexus. Debates about the impact of printing in Europe have focused on two main questions so far: To what extent did printing amplify phenomena already underway or trigger new developments? To what did the handpress create standardization in text and image independently of a process of social construction of printed texts as especially reliable? $?^{24}$ At this point greater attention to the varied trajectories of print technologies in other cultures, from its late adoption in Islam to its early but long adoption in China, can help shed new light on the role of many elements of historical

\footnotetext{
${ }^{23}$ For a detailed discussion of measuring incunabula, see Joseph Dane, The Myth of Print Culture: essays on evidence, textuality and bibliographical method (Toronto: University of Toronto Press, 2003).

${ }^{24}$ Elizabeth Eisenstein, The Printing Press as an Agent of Change, 2 vols. (Cambridge: Cambridge University Press, 1979), or in article form: "Some Conjectures about the Impact of Printing on Western Society and Thought," Journal of Modern History 40 (1968): 1-29. For critiques of the first kind see Anthony Grafton, "The Importance of Being Printed," Journal of Interdisciplinary History 11 (1980): 265-286 and Paul Needham, Review of Eisenstein, in Fine Print: The Review for the Arts of the Book 6 (1980), 23-35. For the second kind of critique see Adrian Johns, The Nature of the Book: Print and Knowledge in the Making (Chicago: University of Chicago Press, 1998) and Elizabeth Eisenstein and Adrian Johns, "AHR Forum: How Revolutionary Was the Print Revolution?" American Historical Review 107.1 (2002), 84-128.
} 
context in shaping the impact of a new technology. ${ }^{25}$ Books like this one that bring together and make accessible expert research on the Chinese case can help book historians in multiple areas of specialization refine their thinking on how to measure and discuss the impacts of printing in different historical contexts.

${ }^{25}$ On book historical studies of Islam see Bloom, Paper before Print: the history and impact of paper in the Islamic world (New Haven: Yale University Press, 2001); Gregor Schoeler, The Genesis of Literature in Islam: From the Aural to the Read, in collaboration with and tr. Shawkat M. Toorawa (Edinburgh: Edinburgh University Press, 2009); George Atiyeh, ed., The Book in the Islamic World: The Written Word and Communication in the Middle East (Albany: State University of New York Press, 1995); Johannes Pedersen, The Arabic Book, tr. Geoffrey French (Princeton: Princeton University Press,1984). 